Javier Fernández de Córdova, Carlos Nivelo-Villavicencio, Carolina Reyes-Puig, Ulyses F.J. Pardiñas and Jorge Brito*

\title{
A new species of crab-eating rat of the genus Ichthyomys, from Ecuador (Rodentia, Cricetidae, Sigmodontinae)
}

https://doi.org/10.1515/mammalia-2019-0022

Received March 8, 2019; accepted October 9, 2019; previously published online December 12, 2019

\begin{abstract}
Based on two adult specimens collected in the Río León (Azuay, Ecuador), we describe a new highland species of a small crab-eating rat of the genus Ichthyomys Thomas (Rodentia, Cricetidae, Ichthyomyini). It is distinguishable from Ichthyomys hydrobates (Winge, 1891), the species phenetically closest to it, by its smaller size, bicolored tail (unicolored in I. hydrobates), broad and heavily fringed hindfoot (narrower and moderately fringed in $I$. hydrobates), and several craniodental traits (e.g. rostrum short broad; nasals anteriorly truncated; interorbital region narrow; supraorbital margins smoothly rounded; supraorbital foramina small, zygomatic plate very narrow; incisors opisthodont; length of M3 half that of M2). The new species occurs in the western Andes in southern Ecuador and is allopatric with Ichthyomys stolzmanni Thomas, 1893, which also has a bicolored tail but is larger. The new species brings the number of Ecuadorean Ichthyomys to four, Ecuador thus becoming the country with the greatest diversity of Ichthyomyini (four genera and eight species).
\end{abstract}

*Corresponding author: Jorge Brito, Instituto Nacional de Biodiversidad (INABIO), Rumipamba 341 y Av. de los Shyris, casilla: 17-07-8976, Quito, Ecuador; and Departamento de Biología, Facultad de Ciencias, Escuela Politécnica Nacional, Quito, Ecuador, e-mail: jorgeyakuma@yahoo.es. https://orcid.org/0000-0002. 3410-6669

Javier Fernández de Córdova: Laboratorio de Ecoacústica, Escuela de Biología de la Universidad del Azuay, Cuenca, 0101981, Ecuador; and Facultad de Ciencias Exactas, Universidad de Buenos Aires, Viamonte 430, Ciudad Autónoma de Buenos Aires, Argentina Carlos Nivelo-Villavicencio: Laboratorio de Mastozoología, Museo de Zoología de la Universidad del Azuay, Cuenca, 0101981, Ecuador Carolina Reyes-Puig: Instituto de Diversidad Biológica Tropical iBOTROP, Museo de Zoología, Instituto BIOSFERA, Colegio de Ciencias Biológicas y Ambientales, Universidad San Francisco de Quito, Campus 15 Cumbayá, Casilla Postal 17-1200-841, Quito, Ecuador Ulyses F.J. Pardiñas: Instituto de Diversidad y Evolución Austral (IDEAus - CONICET), Bv. Brown 2915, 9120 Puerto Madryn, Chubut, Argentina; and Instituto Nacional de Biodiversidad (INABIO), Rumipamba 341 y Av. de los Shyris, casilla: 17-07-8976, Quito, Ecuador
Keywords: Andes; biodiversity; Ichthyomyini; morphology; Neotropics; new species; taxonomy.

\section{Introduction}

Ichthyomyines are the most distinctive group in the rodent subfamily Sigmodontinae. Their morphologic uniqueness embraces several cranial, postcranial and external anatomy autapomorphies (see Voss 1988, 2015). In addition, although few, the available molecular data indicate distant relationships with the remainder of the sigmodontines (Jansa and Weksler 2004, Schenk et al. 2013, Salazar-Bravo et al. 2016). Known as crab-eating rats, the tribe Ichthyomyini includes five genera and 18 species (Pardiñas et al. 2017), mostly concentrated in highlands of tropical Middle America and northern South America (Voss 2015). Recent literature on ichthyomyines includes a number of new locality records, in several cases providing noteworthy range extensions (e.g. Santillán and Segovia 2013, Rodríguez-Posada 2014, Medina et al. 2015, Brito et al. 2016, Caviedes-Solís et al. 2017, Marín-C et al. 2018). Also, new species have been described (Hanson et al. 2015) or are awaiting description (N. Reid, pers. comm. to UFJP in 2018), and new morphological details have been published for known taxa (e.g. Braga and Duda 2017, Catzeflis et al. 2017). This renewed interest is improving our limited knowledge of this group of Neotropical rodents, of which there have been relatively few specimens collected.

Together with Rheomys, Ichthyomys constitutes an extreme in ichthyomyine adaptations for swimming and foraging in rapid and clear freshwaters. Unmistakably recognizable, due to a combination of external (e.g. five separate palmar pads), craniodental (e.g. occipital condyles projecting well behind the rest of the occiput) and soft anatomy traits (e.g. absence of gall bladder), the current alpha taxonomy of Ichthyomys was established by Voss (1988). Voss (1988) arranged eight nominal forms in four species, two being small, Ichthyomys hydrobates (Winge, 1891) and Ichthyomys pittieri Handley and Mondolfi 1963, and two large, Ichthyomys stolzmanni Thomas 1893 and Ichthyomys 
tweedii Anthony 1921. Voss (1988) employed a conservative approach to the taxonomy of ichthyomyines, treating several morphological differences among populations as indicative of races or simply without taxonomic value. This scheme, in particular for Ichthyomys, has remained largely unchanged (see Voss 2015, Pardiñas et al. 2017).

Two adult animals collected almost three decades ago near Nabón, in southern Ecuador, belong to Ichthyomys. Although they are represented by poorly preserved specimens, and field work performed to obtain additional material produced negative results, the available evidence is enough to justify erection of a new species, named herein.

\section{Materials and methods}

Two adult specimens collected in 1990 and originally housed at the Museo Universidad del Azuay (MZUA; Cuenca, Ecuador) stimulated the present study. They were compared with specimens of Ichthyomys preserved in other mammal collections, including the Instituto Nacional de Biodiversidad (MECN; Quito, Ecuador), the Museo de la Escuela Politécnica Nacional (MEPN; Quito, Ecuador) and the Museo de Historia Natural, Universidad de San Marcos (MUSM; Lima, Peru). The morphology of one Peruvian Ichthyomys of the American Museum of Natural History (AMNH; New York, NY, USA) and several specimens referring to Ichthyomys hydrobates housed at the Natural Resource Management, University of Copenhagen (NRM; Copenhagen, Denmark) were assessed through digital photographs. Relevant information concerning members of both the genus and the tribe was gathered from the literature (e.g. Thomas 1893, Anthony 1921, 1923, Voss 1988, 2015). All the studied material is listed in Appendix 1.

All measurements reported here were taken from specimen labels or by use of a digital caliper, (Buffalo Tools, O'Fallon, MO, USA) to $\pm 0.01 \mathrm{~mm}$. The measurements and age classification system are those of Voss (1988). Most anatomical terms follow Voss (1988) or, less often, Carleton and Musser (1989) and Reig (1977); terminology for stomach gross morphology follows Vorontsov (1967) and Carleton (1973). The stomach contents of one specimen were examined using a stereomicroscope Leica EZ4HD 35×, Wetzlar, Germany.

In an effort to obtain additional specimens of the new species, we conducted a field trip to the type locality on the Río León (see Figure 1). In August 2017, 75 Shermanlike traps $(7.5 \times 9 \times 29 \mathrm{~m}, \mathrm{H}$. B. Sherman Traps, Tallahassee, FL, USA) were set there along with 20 Tomahawk-like traps $(14 \times 14 \times 40 \mathrm{~cm}$, Tomahawk Live Trap Company, Tomahawk, WI, USA), which allowed for 285 trap-nights.
Traps were set along ravines, baited with oats, peanut butter, tuna and vanilla, and in such potential refuges as logs, leaf litter, rocks and holes in the substrate. No Ichthyomys were caught.

In order to estimate the distribution and suitable habitat of the species of Ichthyomys living in Ecuador and their possible relevance with respect to the new species described here, we generated ecological niche models (ENMs) for Ichthyomys hydrobates, Ichthyomys stolzmanni and Ichthyomys tweedii. These models, produced with MaxEnt v3.3.3 (Elith et al. 2006, Phillips et al. 2006), were based on recording localities for each species (Supplementary Table S1) and included 19 bioclimatic variables of WorldClim 1.4, derived from the temperature and monthly precipitation, with an approximate resolution of $1 \mathrm{~km}^{2}$ (Hijmans et al. 2005). We performed 50 repetitions with a Jackknife test to estimate the contribution percentage of the variables in the generation of the model (e.g. Phillips et al. 2006, Narvaez-Romero et al. 2018). For the construction of the models, we established a convergence threshold of 0.00001, a maximum of 1000 iterations and a regularization parameter of 1 . In the models generated by each repetition were 20 random points (separated by more than $10 \mathrm{~km}$ ) within the extension of the model to extract the values of the environmental layers with the greatest contribution. We generated a correlation matrix with the values extracted from the variables that presented some degree of contribution to the model (i.e. $\geq 1 \%$ ). With correlograms, we identified and eliminated highly correlated variables (statistical $r>0.8$ ). A final model was run with the variables that contribute significantly and that are not correlated for each species. To evaluate whether the generated models are better than random predictions, we used the jackknife validation proposed by Pearson et al. (2007) for small records.

\section{Results}

Family Cricetidae Fischer, 1817

Subfamily Sigmodontinae Wagner, 1843

Tribe Ichthyomyini Vorontsov, 1959

Genus Ichthyomys Thomas, 1893

Ichthyomys pinei $\mathrm{sp} . \mathrm{n}$. (Figures 2-5; Table 1)

Pine’s Crab-eating Rat or Rata Cangrejera de Pine

\section{Holotype}

MZUA 234, an adult (age classification 6/?/a) pregnant female represented by a fragmentary cranium and mandible and skin (prepared from the specimen originally 

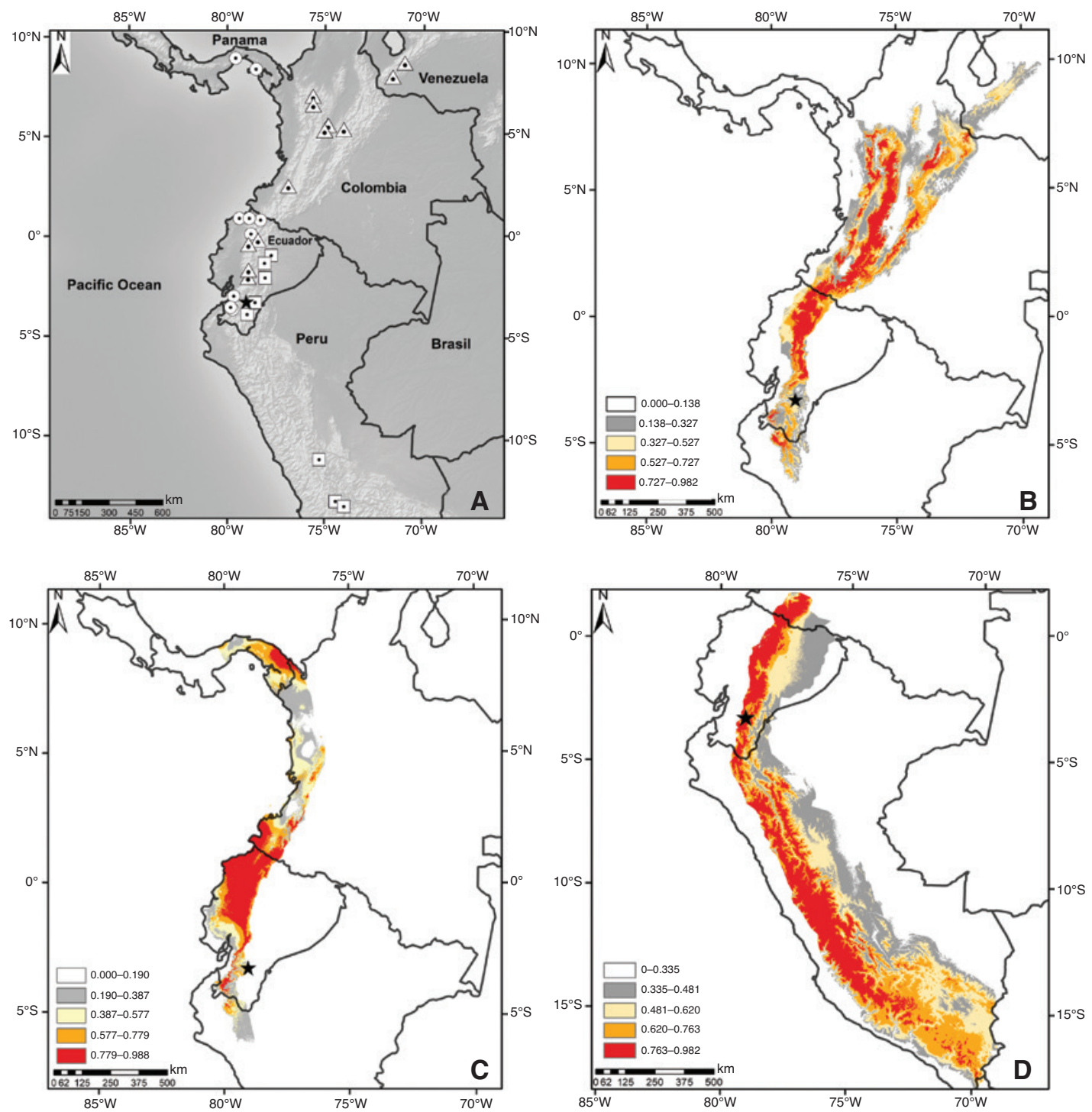

Figure 1: The gradient of coloration represents the ecological niche model for each species, the probabilities of habitat suitability vary between 0 (lower probability of habitat based on bioclimatic variables) - 0.9 (greater probability of suitable habitat based on bioclimatic variables). Localities (A; see Supporting Information S1) for species of Ichthyomys in Ecuador, I. hydrobates (triangles), I. tweedii (circles), I. stolzmanni (squares) and I. pinei, sp. nov. (star); ENMs for I. hydrobates (B), ENM of I. tweedii (C) and ENM of I. stolzmanni (D).

preserved in fluid with formalin) in good condition; collected by Paul Carrasco on 7 August 1990.

\section{Type locality}

La Playa $\left[3.322772^{\circ} \mathrm{S}, 79.062210^{\circ} \mathrm{W}\right.$ (coordinates taken by GPS at the site of collection), elevation $2600 \mathrm{~m}]$, Río León, Parroquia and Cantón Nabón, Provincia del Azuay, Ecuador (Figure 1).

\section{Paratype}

MECN 5613, an adult (age classification 5/?/a) female represented by a crushed cranium and mandible partially covered by dry tissues, with carcass in ethanol (prepared from the specimen originally preserved in formalin); collected at the type locality by P. Carrasco on 7 August 1990.

\section{Etymology}

This species is named in honor of Ronald H. Pine (Lawrence, KS, USA). Dr. Pine has engaged in vertebrate surveys in various countries in five continents, and has published numerous scholarly articles, mostly focused on Latin American bats, rodents and marsupials. The species epithet is formed from the surname "Pine", taken as a noun in the genitive case, with the Latin suffix " $\mathrm{i}$ " (ICZN 31.1.2). 
A

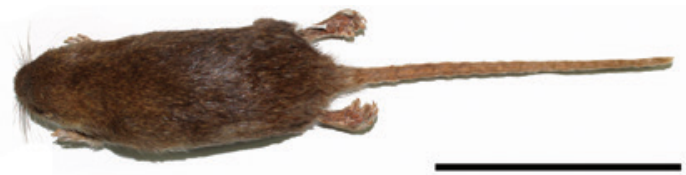

C

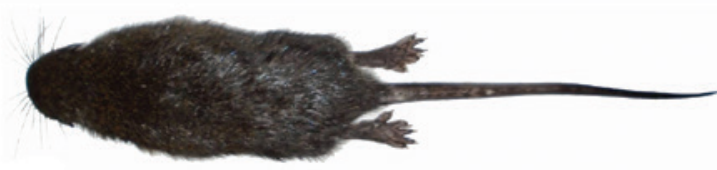

E

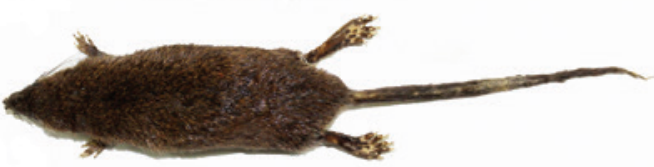

G

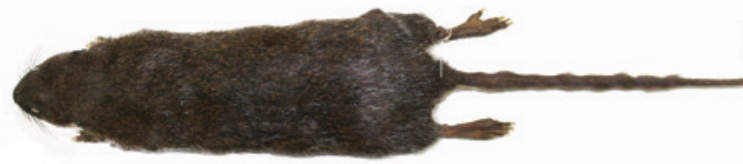

B

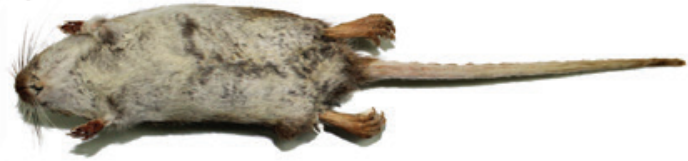

D

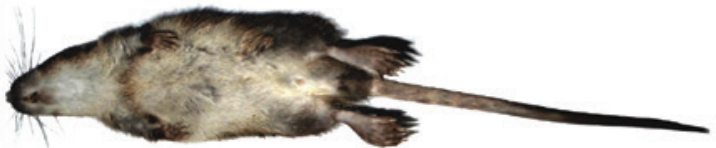

$\mathbf{F}$
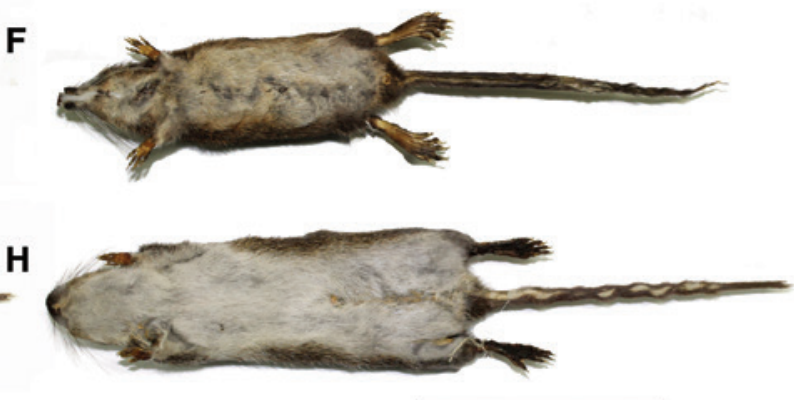

Figure 2: Dorsal and ventral views of stuffed study skins of Ecuadorean species of Ichthyomys, including (A, B) adult female I. pinei, sp. nov. (MZUA 234, holotype); (C, D) adult male I. stolzmanni (MECN 4914); (E, F) adult male I. tweedii (MECN 12229); (G, H) adult male I. hydrobates (MEPN 5834).

Scale $=10 \mathrm{~mm}$.

\section{Nomenclatural statement}

A life science identifier (LSID) number was obtained for the new species (Ichthyomys pinei): urn:Isid:zoobank. org:pub:xxxxx.

\section{Diagnosis}

A small species of Ichthyomys (length of head plus body $\sim 130 \mathrm{~mm}$, length of hindfoot with claw $<35 \mathrm{~mm}$, alveolar length of maxillary toothrow $\sim 3.7 \mathrm{~mm}$ ), characterized by the following combination of characters: dorsal coloration brown; tail sharply bicolor and slightly longer than head plus body; ventral surface of hindfoot dark brown; nasals short $(<9.9 \mathrm{~mm})$; incisors opisthodont; length of M3 half that of M2; $\mathrm{m} 1$ anterocone broad.

\section{Description}

Dorsal pelage rusty brown (both specimens were originally preserved in fluid, so some coloration changes may have occurred); soft, dense and woolly (Figure 2A); ca. $10 \mathrm{~mm}$ long with a dark gray basal band of ca. $8 \mathrm{~mm}$ and brown apical portion of ca. $2 \mathrm{~mm}$; dark guard hairs ca. $14 \mathrm{~mm}$ long. Ventral pelage whitish (Figure 2B), with gray basal portion of ca. $5 \mathrm{~mm}$ and whitish apical portion of ca. $2 \mathrm{~mm}$. Mystacial vibrissae numerous, dark and stiff, reaching past the ear when laid back. Tail slightly longer than the head plus body (ca. 105-115\% of the head plus body length), thick, densely covered with hair obscuring scalation; bicolored (brown above, whitish below) except for the terminal $25 \mathrm{~mm}$ which is brown all-around, with apical tuft of ca. $4 \mathrm{~mm}$.

Manus with dorsal spot pale brown; metacarpus and digits covered by whitish hair (Figure 3A); pollex small and with nail, other manual digits moderately short and with short but robust claws with rounded ends. Ungual tufts not projecting beyond the basal portion of the claws. Palm almost entirely covered by five pads, the thenar and hypothenar divided by a shallow groove; pads superficially covered by a network of stretch marks. Hindfoot short and broad, with small dorsal metatarsal spot of brown hair, the remainder whitish (Figure 3C). Digits short and increasingly broad proximally, ending in sharp, curved claws and with hardly developed ungual tufts. Plantar surface dark brown, with five well-defined tubercles, a large thenar and four fleshy interdigital pads. Surface of pads covered with microridges; remainder of sole smooth; between the tarsal and digital pads, a perceptible space that reflects the axis of pes pronation. Along pes margins and between digits, a continuous comb of whitish stiff hair, ca. $2 \mathrm{~mm}$ in length. Small webs connect digits I-II 

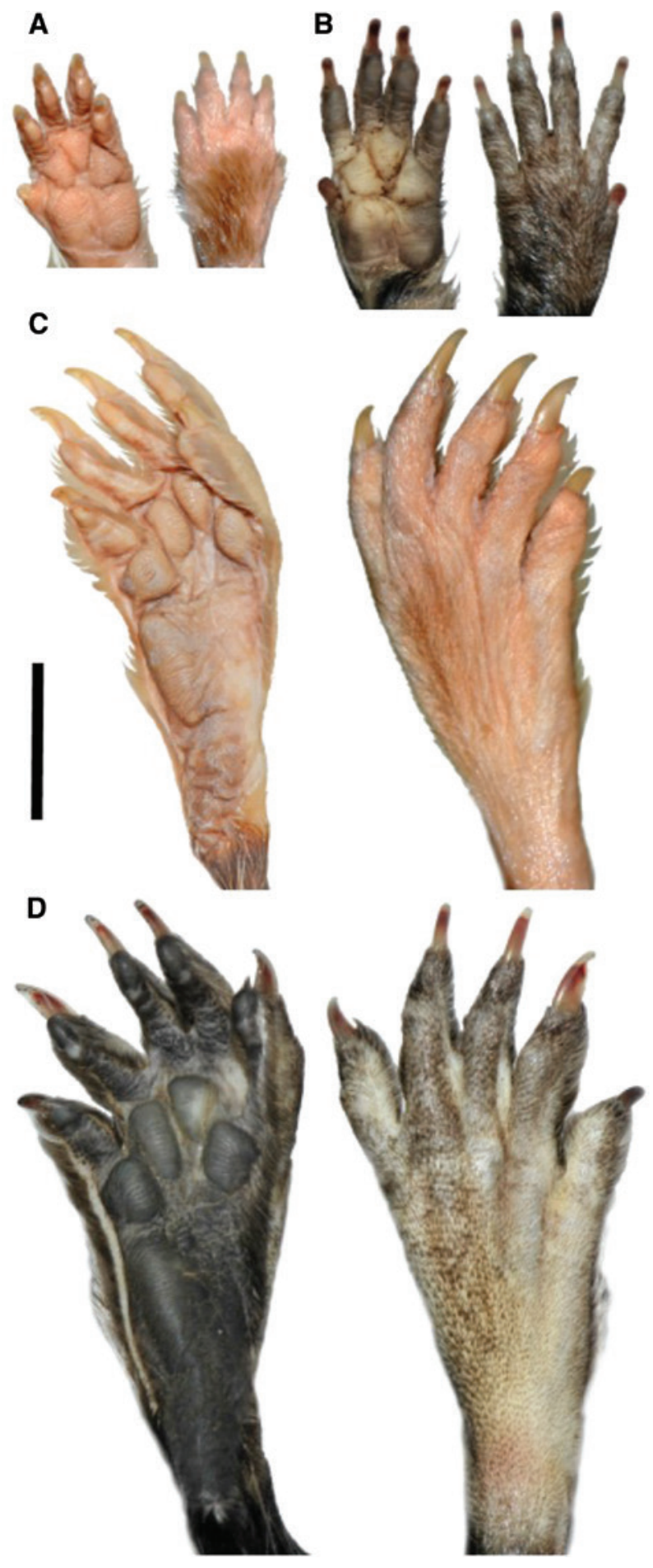

Figure 3: Left manus ( $A, B$ ) and left pes (C, D) in ventral (on left) and dorsal (on right) views of two species of Ichthyomys: (A, C) adult female Ichthyomys pinei (MECN 5613, paratype); (B, D) adult male Ichthyomys stolzmanni (MECN 4914).

Scale $=10 \mathrm{~mm}$.

and IV-V; webs between digits II-III and III-IV extend just beyond the first interphalangeal joints. Metatarsal relative lengths IV $<$ III $>$ II $>$ V $>$ I. MECN 5613 with six mammae in postaxial, abdominal and inguinal pairs, according to Voss's (1988:277-278) scheme, whereas Pacheco and Ugarte-Núñez (2011:659) interpreted the pairs as pectoral, abdominal and inguinal in Ichthyomys stolzmanni.

Few trenchant morphological characters can be distinguished in the two partially crushed skulls of Ichthyomys pinei available for study (Figure 4). The rostrum is short and broad and nasals anteriorly truncated, markedly expanded in their anterior half with sharp posterior ends placed well beyond the lacrimal level. Zygomatic notches absent. Interorbital region narrow, and supraorbital margins smoothly rounded. Supraorbital foramina small and near interorbital constriction. Zygomatic plate very narrow and masseteric tubercle small. Incisive foramina moderately short, narrow and parallel-sided; premaxillary process forming a bony capsule filling $2 / 3$ of the incisive foramina cavity; its posterior end extending to the level of anterior faces of M1s. Bony palate flat, without ridges or depressions; palate with minute posterior palatine foramina at the level of M1; palate apparently long (anterior margin of mesopterygoid fossa damaged); posterolateral palatal pits small and simple (or double). Parapterygoid plates damaged, but apparently present as a ridge formed by palatine and alisphenoid. Pattern of carotid circulation type 3 (sensu Voss 1988:298).

Mental foramen small, barely visible in dorsal view and just anterior to $\mathrm{m} 1$; masseteric crest poorly developed; rounded capsular process inconspicuous near the base of coronoid process (Figure 4). Neither holotype nor paratype currently possesses the tip of this last structure, but judging from what is left, it was robust, wide and moderately recurved. Condyloid process with welldefined articular surface and well-developed postcondyloid process. Horizontal ramus markedly excavated internally below the mylohyoid line; retromolar fossa noticeable.

Upper incisors opisthodont (Figure 4). Molar structure obscured by advanced wear and poor preservation (Supplementary Figure S1). Enamel remarkably thick. Occlusal surface of M1 subrectangular; M2 bilobed, with posterior lobe narrower; M3 quite small, its length about half that of M2; anterocone of $\mathrm{m} 1$ moderately large; $\mathrm{m} 3$ bilobed.

Gall bladder absent (both holotype and paratype examined). Stomach unilocular and hemiglandular (Figure 5). Lining of the stomach has widespread, rugged, cornified epithelium, both in corpus and antrum; glandular epithelium restricted to a small portion of the greater curvature. Borderline fold between horny and glandular portions of the stomach (=bordering fold sensu Carleton 1973) remarkable in that its thickness, surpassing to the left the level of a shallow incisura angularis and has 


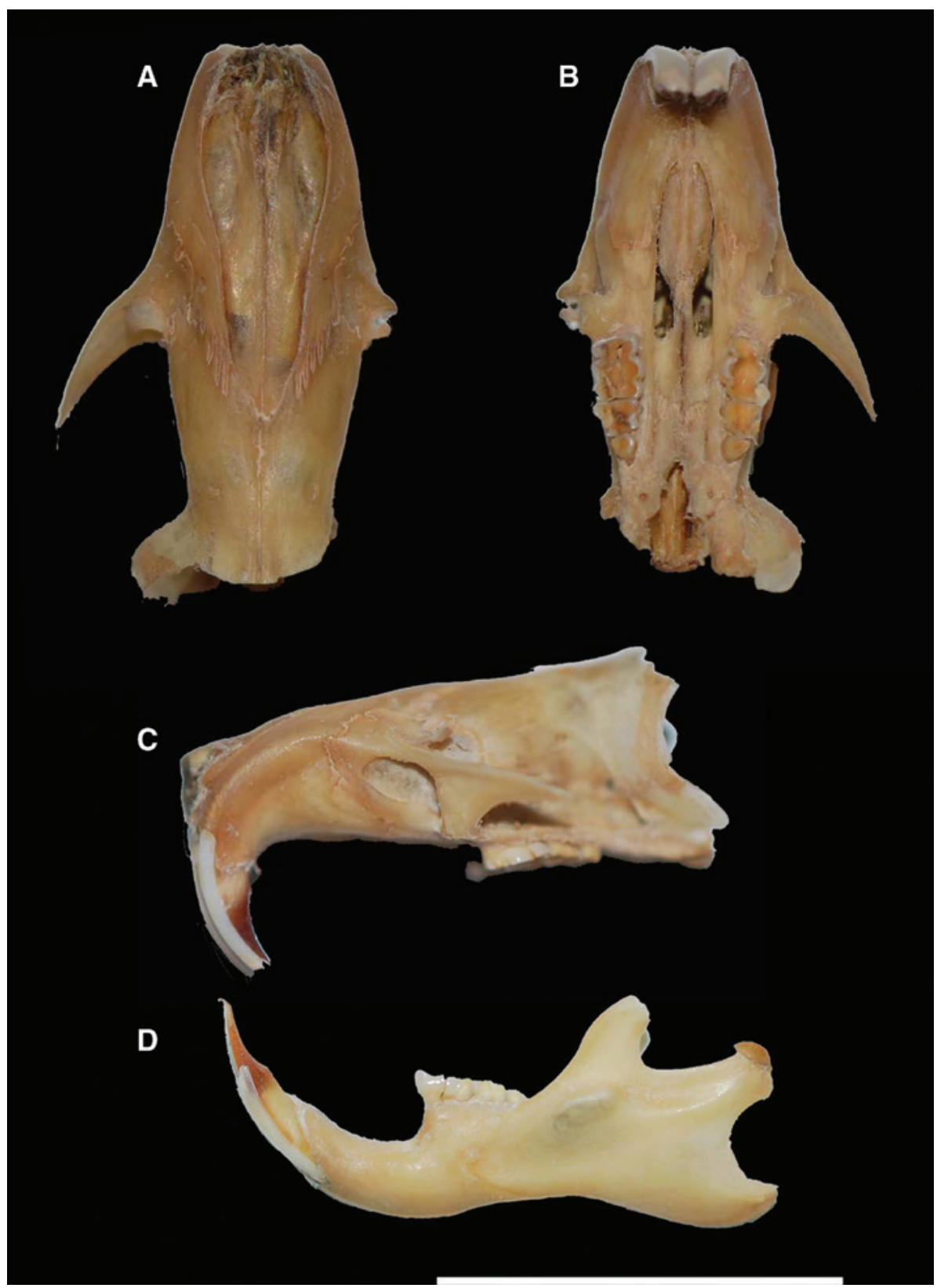

Figure 4: Skull of the holotype of Ichthyomys pinei, sp. nov., from La Playa, Azuay, Ecuador (MZUA 234): cranium in dorsal (A), ventral (B) and left lateral (C) views, and (D) left dentary in labial view.

Scale $=10 \mathrm{~mm}$.

a putative minute "orifice". Plica angularis well developed, in combination with a moderately developed pars pyloricus.

\section{Measurements (in $\mathrm{mm}$ ) of the holotype}

Length of the head plus body 128; length of the tail 148; length of the hindfoot (with claw) 33; length of the ear (from notch) 7; length of the upper diastema 7.5; length of the maxillary toothrow 3.7 ; length of the incisive foramen 5.3; breadth of the upper incisor tips 2.2; breadth across the incisive foramina 1.6; breadth of the palatal bridge 2.2; length of the nasals 9.8; breadth across the nasals 3.6; least interorbital breadth 4.3; breadth of the braincase 13.2; breadth of the zygomatic plate 1.3; breadth of M1 1.3; height of the upper incisor 5; depth of the upper incisor 1.6. Measurements for the paratype are shown in Table 1. 

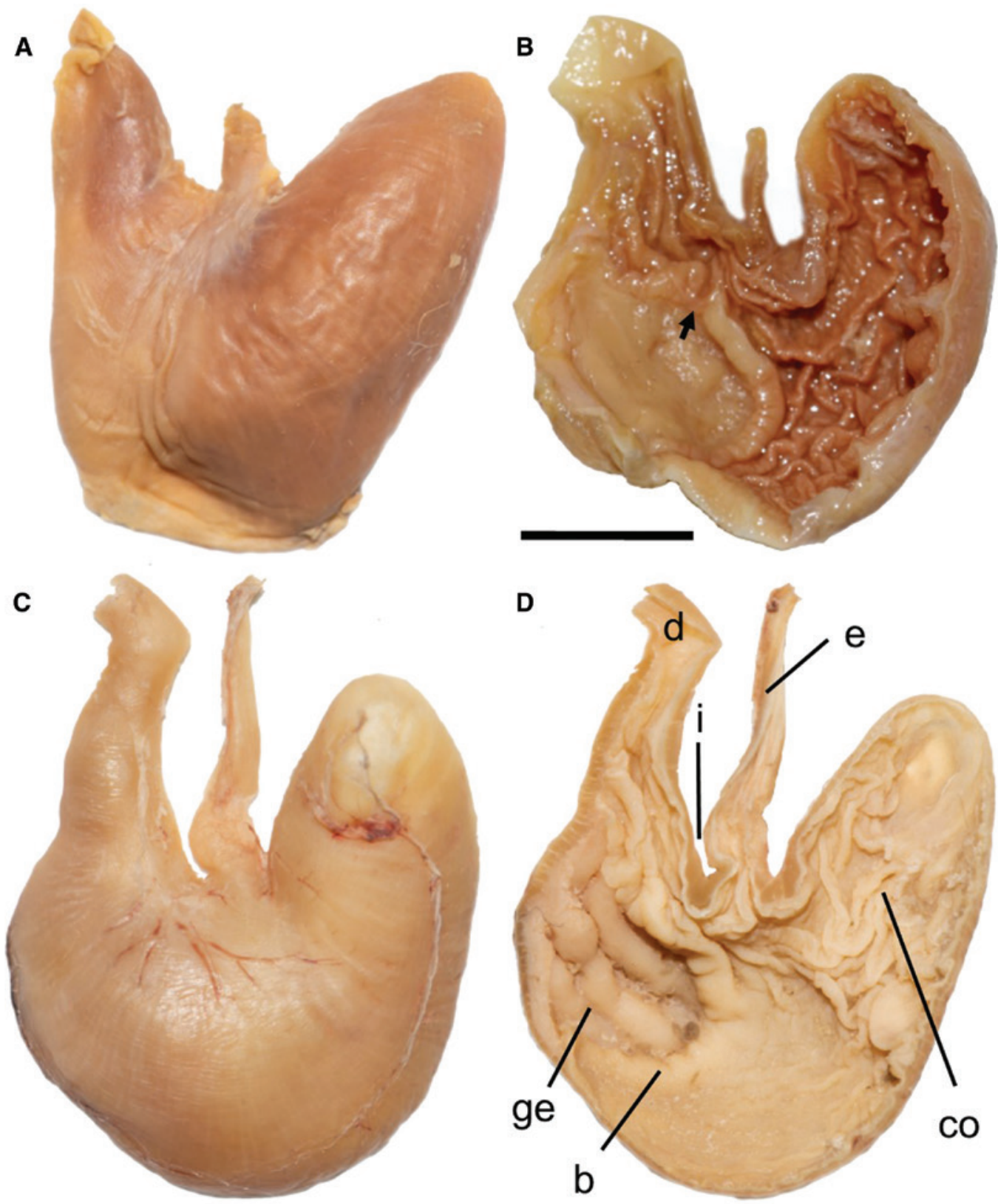

Figure 5: Mid-dorsal portions in external (A, C) and internal (B, D) views of stomachs of Ichthyomys pinei, sp. nov. (A, B; MECN 5613 , paratype, from La Playa, Azuay, Ecuador) and I. stolzmanni (C, D; MEPN 12672).

References: $b$ = borderline fold between cornified (co) and glandular epithelia (ge), $d=$ duodenum, e = esophagus, $i=$ incisura angularis. Arrow points to an apparent minute "orifice". Scale $=10 \mathrm{~mm}$.

Comparisons: The placement of pinei in Ichthyomys is supported by its possession of certain generic morphological traits, including, among others, the absence of gall bladder (being an autapomorphic character for the genus in the context of the tribe), gross morphology of the stomach with a reduced glandular portion, small but visible ears, a well-developed philtrum, a manus with five separate pads and various cranial features (e.g. shortening of the nasals, supraorbital foramina opening dorsally between the orbits; Figure 6). Additional diagnostic characters of Ichthyomys (see Voss 1988:328) cannot be checked in Ichthyomys pinei due to the incompleteness of the available material.

Metrically, Ichthyomys pinei is one of the smaller species of the genus Ichthyomys, rivalling in this respect the Venezuelan endemic Ichthyomys pittieri (Table 1; see 


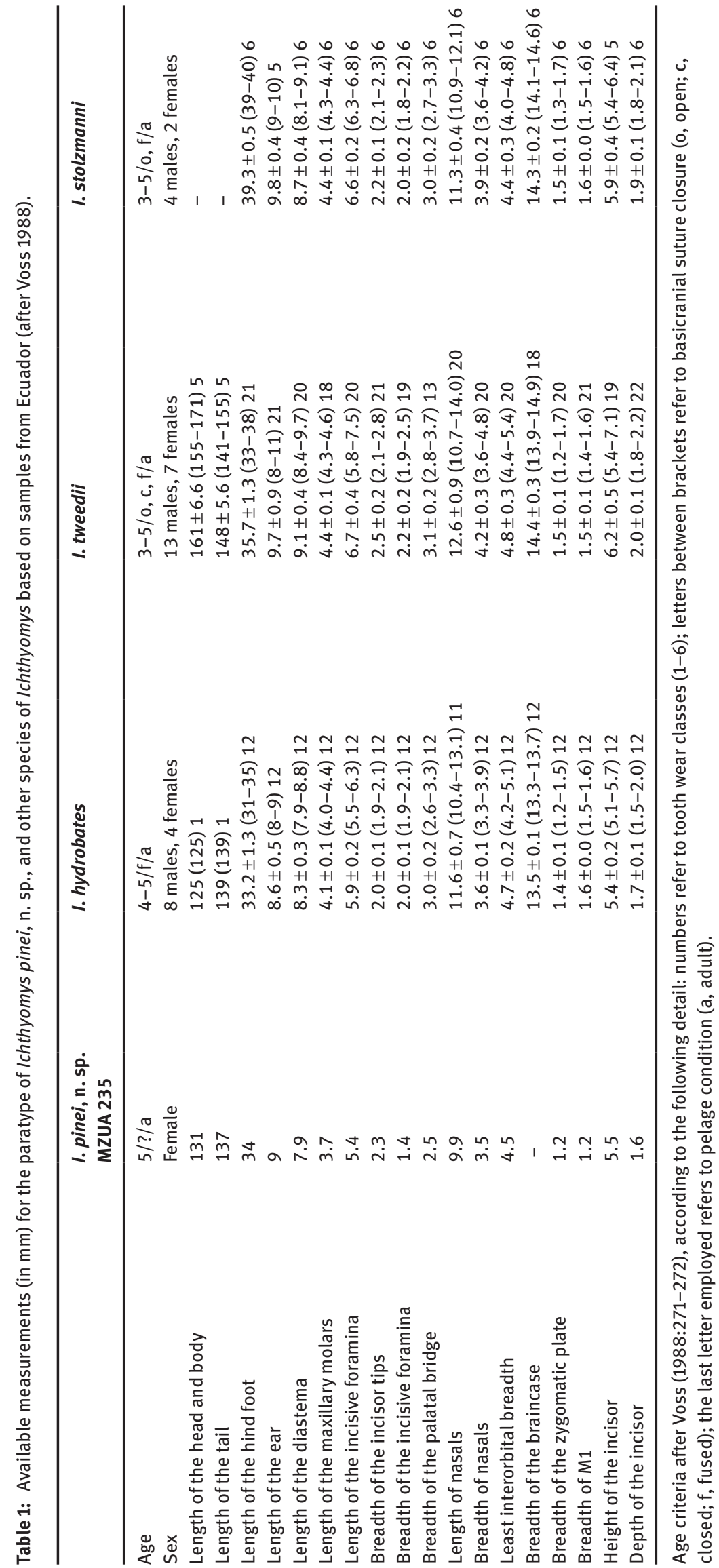




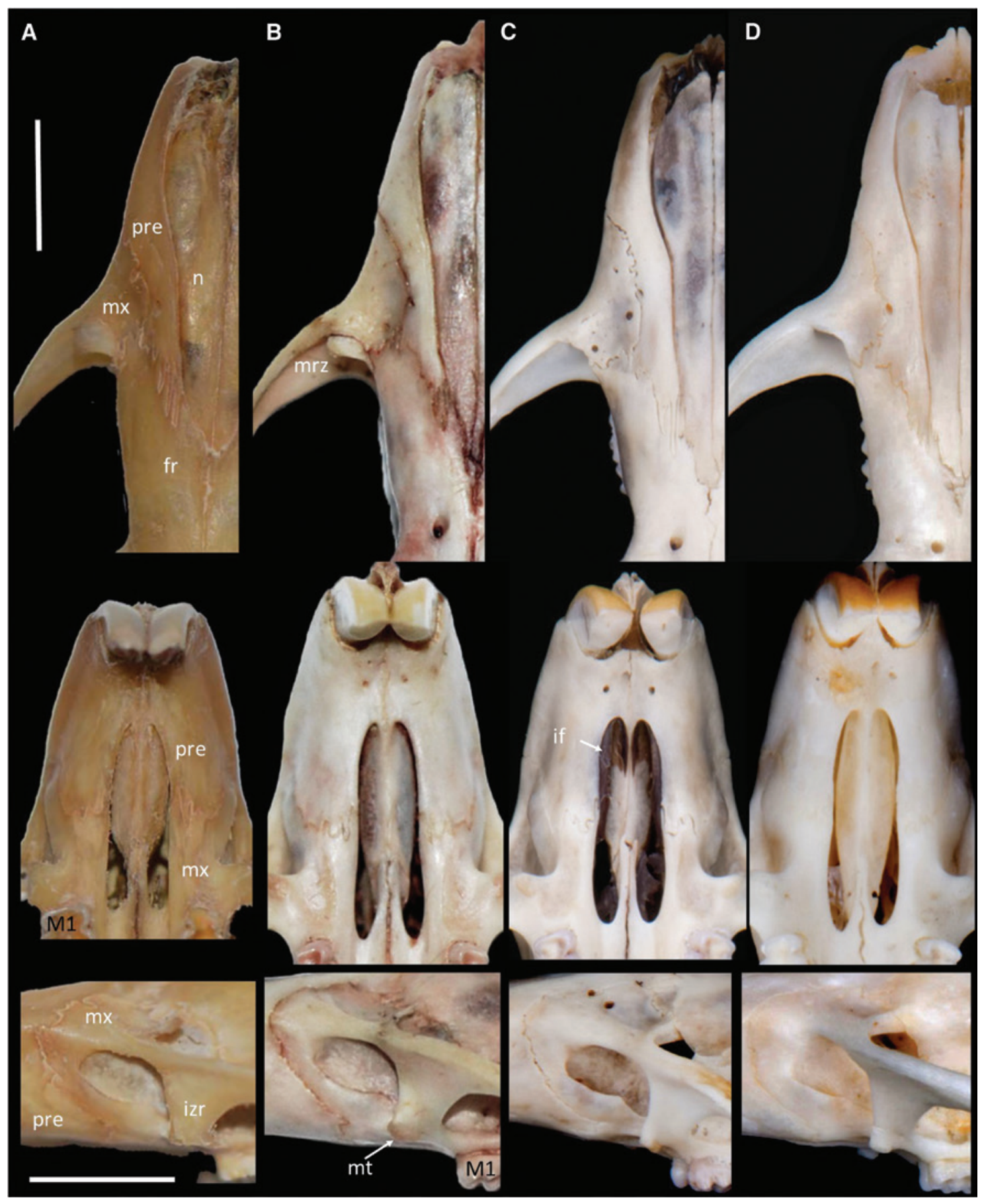

Figure 6: Skull regions in species of Ichthyomys known from Ecuador: at top interorbit and rostrum in dorsal view; in middle rostrum in ventral view; at bottom zygomatic plate in lateral view in (A) I. pinei, sp. nov. (MZUA 234, adult female); (B) I. stolzmanni (MECN 4914, adult male); (C) I. tweedii (MECN 12229, adult male); (D) I. hydrobates (MEPN 5834, adult male); $\mathrm{fr}=$ frontal; if = incisive foramen; izr = lower root of the zygomatic; $\mathrm{mrz}=$ maxillary root of the zygomatic; $M 1=$ first upper molar; $\mathrm{mx}=$ maxillary; pre= premaxillary; $\mathrm{n}=\mathrm{nasal} ; \mathrm{mt}=\mathrm{masseteric}$ tubercle.

Scale $=5 \mathrm{~mm}$.

Voss 1988). Although these two species have similar maxillary toothrow lengths, they differ in the dimensions of the nasals and hindfoot. The nasals in I. pinei are absolutely shorter and narrower than in I. pittieri, as well as in the other species of the genus, and I. pittieri has an absolutely shorter and narrower pes (Figure 7). Proportions of 

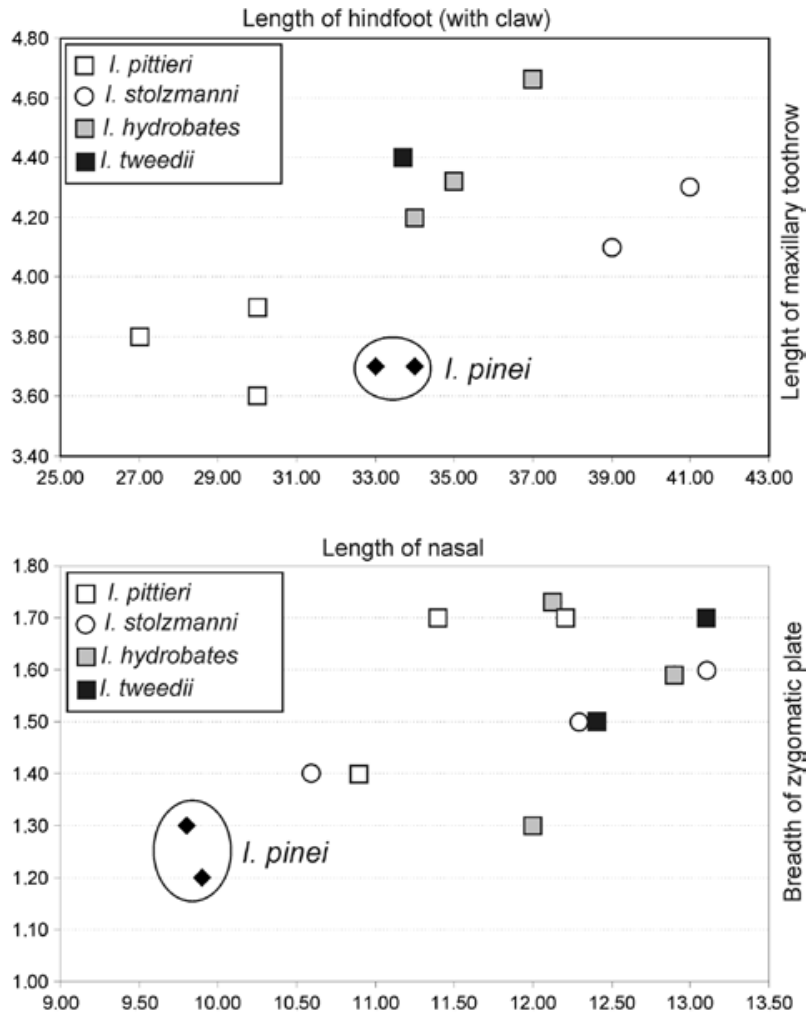

Figure 7: Scatterplots illustrating selected metric comparisons among the species of Ichthyomys.

the nasals are also useful in distinguishing I. pinei from Ichthyomys hydrobates. The shortening of the rostrum in I. pinei contrasts with the longer rostra in the other Ecuadorean species of the genus. Perhaps associated with this is the procumbence of upper incisors, slightly opisthodont in I. pinei versus orthodont in the remainder Ichthyomys.
From the recognized species of Ichthyomys, Ichthyomys pinei is easily distinguishable from the two small forms (i.e. Ichthyomys hydrobates and Ichthyomys pittieri), owing to its bicolored tail (Figure 2). In addition, I. pittieri differs from $I$. pinei by its unique $\mathrm{m} 3$ with a minute posterior lobe (see García et al. 2012: fig. 3), while the remaining species in the genus, including pinei, have bilobed m3s (Voss 1988). Clearly, I. hydrobates (see Voss 1988, Marín-C et al. 2018) is the species phenetically closest to I. pinei. Ichthyomys pinei is distinguishable by the combination of generally smaller size (Table 1, Figure 7) and a broader and heavily fringed hindfoot. Ichthyomys pinei shares, with the apparently widespread Ichthyomys stolzmanni (see Brito et al. 2016), the bicolored tail, but their conspecificity can be ruled out owing to trenchantly different sizes. In addition, the rugged cornified stomach epithelium is more restricted in I. stolzmanni than in I. pinei (Figure 5). Size difference also serves to separate I. pinei from Ichthyomys tweedii, along with additional characters, including a broad skull and unicolored tail in the latter (Voss 1988). Table 2 summarizes the main morphological traits distinguishing the five species now placed in Ichthyomys (see also Supplementary Figure S2 and Figure 6).

Distribution: Known only from the type locality in the upper course of the Río León (Azuay, Ecuador; Figure 1).

\section{Potential distribution}

The ENMs generated to preliminarily estimate the distribution of three species of Ichthyomys were statistically significant for all species, according to the validation of Pearson etal.(2007) $(D=1 ; p<0.01)$. ENMs for Ichthyomys hydrobates

Table 2: Selected morphological differences among species of Ichthyomys; compiled from several sources.

\begin{tabular}{|c|c|c|c|c|}
\hline I. pinei, n. sp. & I. hydrobates & I. pittieri & I. stolzmanni & I. tweedii \\
\hline Small-bodied & Small-bodied & Small-bodied & Large-bodied & Large-bodied \\
\hline Bicolored tail & Unicolored tail & Unicolored dark tail & Bicolored tail & Unicolored tail \\
\hline $\begin{array}{l}\text { Broad and heavily } \\
\text { fringed hindfoot }\end{array}$ & $\begin{array}{l}\text { Broad and less } \\
\text { fringed hindfoot }\end{array}$ & $\begin{array}{l}\text { Moderately narrow and } \\
\text { less fringed hindfoot }\end{array}$ & $\begin{array}{l}\text { Broad and heavily } \\
\text { fringed hindfoot }\end{array}$ & $\begin{array}{l}\text { Broad and heavily fringed } \\
\text { hindfoot }\end{array}$ \\
\hline $\begin{array}{l}\text { Ventral surface of } \\
\text { hindfoot brown }\end{array}$ & $\begin{array}{l}\text { Ventral surface of } \\
\text { hindfoot black }\end{array}$ & $\begin{array}{l}\text { Ventral surface of } \\
\text { hindfoot black }\end{array}$ & $\begin{array}{l}\text { Ventral surface of } \\
\text { hindfoot black }\end{array}$ & $\begin{array}{l}\text { Ventral surface of hindfoot } \\
\text { black }\end{array}$ \\
\hline $\begin{array}{l}\text { Metatarsal } \\
\text { configuration }\end{array}$ & $\begin{array}{l}\text { Metatarsal } \\
\text { configuration }\end{array}$ & $\begin{array}{l}\text { Metatarsal } \\
\text { configuration }\end{array}$ & $\begin{array}{l}\text { Metatarsal } \\
\text { configuration }\end{array}$ & $\begin{array}{l}\text { Metatarsal configuration } \\
\text { IV }>\text { III }>\text { II }>\text { V }>\text { I }\end{array}$ \\
\hline IV $<$ III $>$ II $>$ V $>$ I & IV $>$ III $>$ II $>$ V $>$ I & IV $>$ III $>$ II $>$ V $>$ I & IV $>$ III $>$ II $>$ V $>$ I & \\
\hline $\begin{array}{l}\text { Incisors in opisthodont } \\
\text { configuration }\end{array}$ & $\begin{array}{l}\text { Incisors in orthodont } \\
\text { configuration }\end{array}$ & $\begin{array}{l}\text { Incisors in orthodont } \\
\text { configuration }\end{array}$ & $\begin{array}{l}\text { Incisors in orthodont } \\
\text { configuration }\end{array}$ & $\begin{array}{l}\text { Incisors in orthodont } \\
\text { configuration }\end{array}$ \\
\hline $\begin{array}{l}\text { Small masseteric } \\
\text { tubercle }\end{array}$ & $\begin{array}{l}\text { Large masseteric } \\
\text { tubercle }\end{array}$ & $\begin{array}{l}\text { Large masseteric } \\
\text { tubercle }\end{array}$ & $\begin{array}{l}\text { Large masseteric } \\
\text { tubercle }\end{array}$ & Large masseteric tubercle \\
\hline Bilobed m3 & Bilobed m3 & Single $\mathrm{m} 3$ & Bilobed m3 & Bilobed $\mathrm{m} 3$ \\
\hline
\end{tabular}


projected a higher probability of finding an extensive suitable habitat in the Andes of Colombia, extending toward the Andean slopes and part of the southwestern foothills of Ecuador and northernmost Peru, but excluding from where Ichthyomys pinei is recorded (Figure 1B). The variables that had a greater contribution in the generation of the model were Isothermality (BIO2/BIO7) $\left({ }^{\star} 100\right)(\mathrm{BIO} 3)$ and Mean Temperature of Warmest Quarter (BIO10) (Supplementary Table S2). The model generated for Ichthyomys tweedii projected a greater probability of suitable habitat in two disjunct areas, in central Panama, and in the southwestern foothills of Colombia and the lowlands and western foothills of northcentral Ecuador, again excluding the known area of occurrence for I. pinei (Figure 1C). The variables that contributed the highest percentage to the generation of the model were the Temperature Seasonality (standard deviation *100) (BIO4) and Isothermality (BIO2/BIO7) ( $\left.{ }^{\star} 100\right)$ (BIO3) (Supplementary Table S2). By contrast, the type locality of the new species is embedded in suitable habitat projected by the model for Ichthyomys stolzmanni, extensively covering the eastern Andean slopes of Ecuador and Peru (Figure 1D). The variables that had the greatest contribution to the generation of the model were Isothermality (BIO2/BIO7) ( $\left.{ }^{\star} 100\right)$ (BIO3) and Temperature Seasonality (standard deviation *100) (BIO4) (Supplementary Table S2).

\section{Natural History}

The type locality of Ichthyomys pinei is in an interandean valley in the temperado zoogeographic region (Albuja et al. 2012), characterized by the "Arbustal semideciduo" (Ministerio del Ambiente 2013) as the dominant vegetation. At the collection site of $I$. pinei, the Río León is clear, ca. $8 \mathrm{~m}$ wide and less than $1 \mathrm{~m}$ deep, and has a rocky bottom. The banks of the river are partially eroded by flooding, although provided with riparian shrubs (Supplementary Figure S3). The adult female MECN 5613, taken in August 1990, was pregnant with two embryos (no measurements recorded). Other sigmodontine rodents captured at the type locality were Akodon mollis Thomas, 1894; Oligoryzomys sp.; Phyllotis andium Thomas, 1912; and Thomasomys taczanowskii (Thomas, 1882).

\section{Conservation}

The current conservation status of Ichthyomys pinei would have to be listed as Data Deficient. However, the type locality as well as several other portions of the Río León are included in gold mining projects (ARCOM 2015). The potential negative impacts of the mining should be monitored carefully, particularly taking into account that deforestation and water pollution could be critical in regard to the persistence of this ichthyomyine.

\section{Remarks}

Stomach contents of the two specimens were larvae of the insect order Trichoptera. The fragmentary nature of the two specimens of the new species reflects the difficulty of collecting these elusive rodents; probably they were obtained manually by means of a blow to the head.

\section{Discussion}

To work with small samples in taxonomy is often problematic, a fact intensified when studied genera embrace poorly known forms mostly represented by few specimens from scattered localities. Beyond the obvious difficulties (e.g. limited sample sizes directly impede our perception of non-geographic variations), several commonly employed means of demonstrating potential differences of taxonomic value, such as morphometric analyses, may be deeply affected. Many species of sigmodontines have been described on the basis of small samples, and this happened not only during the "typological period" of our gaining knowledge of the subfamily (Patton et al. 2015). Of the several species named in recent decades, a considerable number were originally based on samples of fewer than five individuals (e.g. Microakodontomys transitorius, Rhagomys longilingua, Abrawayaomys chebezi, Tanyuromys thomasleei; see Hershkovitz 1993, Luna and Patterson 2003, Pardiñas et al. 2009, Timm et al. 2018). Ichthyomyines are not an exception in this respect, as is exemplified by Ichthyomys pittieri, Neusticomys peruviensis, Neusticomys venezuelae (Anthony, 1929), etc. (see Handley and Mondolfi 1963; Musser and Gardner 1974). Our description of Ichthyomys pinei demonstrates how difficult it is to obtain specimens of these poorly known aquatic rodents.

Considerable changes in skull morphology, both quantitative and qualitative, occur in members of the genus Ichthyomys during ontogeny (Voss 1988, Pacheco and Ugarte-Núñez 2011, Brito et al. 2016). In order to partially remediate this situation, in taxonomic work, comparison among specimens at the same stage of development is advisable. Fortunately, although Ichthyomys pinei is represented by only two specimens, both are adults. Assuming that the holotype and paratype adequately reflect the morphological 
space of the new species, the combination of two measurements, the length of the hindfoot and the length of the maxillary toothrow, are enough to separate I. pinei from previously described Ichthyomys. Indeed, if the geographical provenance of $I$. pinei is properly dimensioned, its isolation in an interandean valley provides additional support for its taxonomic uniqueness. For other cricetid species apparently sharing a similar distributional pattern (e.g. Phyllotis haggardi, and Reithrodontomys soederstroemi), see Arellano 2015, and Steppan and Ramirez 2015.

The genus Ichthyomys probably includes additional diversity. Ichthyomys stolzmanni was treated by Voss (1988) as having two subspecies, the nominotypical and I. s. orientalis Anthony 1923. Although Pacheco and UgarteNúñez (2011) synonymized these names, they mentioned an undetermined specimen (AMNH 10109/11817, skull and skin, respectively) from northeastern Peru, which could refer to I. stolzmanni or represent an undescribed species (see Anthony 1923:8; Supplementary Figure S4). Thus, the record attributed to I. stolzmanni from an eastern Ecuadorean locality by Brito et al. (2016) acquired a new significance. As they noted, this specimen from the Río Jurumbuno has about half of its tail bicolored proximally, with its distal half dark all around. This specimen invites a reappraisal of the contents of I. stolzmanni. The extensive range attributed to this species, extending over at least 15으 of latitude (Brito and Pardiñas 2017), includes considerable environmental heterogeneity and significant geographic barriers.

The taxonomy of Ichthyomys hydrobates also deserves more intense study. Cabrera (1961) and Voss (1988) treated I. hydrobates, Ichthyomys nicefori Thomas, 1924 and Ichthyomys soderstromi de Winton, 1896, as constituting three subspecies of I. hydrobates. Voss (1988:334) justified treating these three nominal taxa as conspecific by writing "since hydrobates, nicefori, and soderstromi resemble one another in size, in the relative slenderness of their rostra and in the uniform color of their tails, it seems more useful to draw attention to these resemblances by a hypothesis of conspecificity than to emphasize small differences by retaining each as a separate species". However, Voss (2015) no longer recognized the subspecies of $I$. hydrobates, although he continued to include I. nicefori and I. soderstromi in I. hydrobates. He wrote (Voss 2015:285) "whether these three nominal taxa currently synonymized under this binomen (I. hydrobates) are really conspecific remains to be convincingly demonstrated". Later, however, new material from Colombia came to be classified employing a trinomial scheme, and subtle differences in pelage coloration were emphasized (see Marín-C et al. 2018:238).
Current ichthyomyine classification provides an example of how non-availability of specimens can affect taxonomic hypotheses. Not only are various species known from only a few animals, but samples are scattered across thousands of square kilometers and, in several cases, it is difficult to assess non-geographic variation. For example, Voss (1988: fig. 37) depicted trenchant cranial differences between Ichthyomys hydrobates and Ichthyomys soderstromi (see also Marín-C et al. 2018). However, he took the conservative approach of treating these forms as subspecies, although he ceased to do so in 2015 (see earlier text). DNA analysis might very well end up supporting neither scheme. An instructive example of this sort of thing is illustrated by the recently described Neusticomys vossi Hanson et al. 2015. Voss (1988: 343-343) detected mensural and morphological differences among Colombian and Ecuadorean samples cautiously treated by him as all representing Neusticomys monticolus Anthony 1921. Addition of DNA analyses to these observations resulted in description of a new species (see Hanson et al. 2015). Most of the recognized taxa of ichthyomyines still lack associated molecular markers (Voss 2015); extensive utilization of this kind of data will probably trigger a substantial reworking of the tribe's classification.

However, molecular information by itself will not elucidate the boundaries between taxa of Ichthyomyini. Morphological information should continue to be gathered, and the recognition of Ichthyomys pinei provides an example of the results that can be gained thereby. In particular, gross stomach morphology in Ichthyomys deserves comment here. Although the stomach morphology of $I$. pinei agrees overall with that of figured stomachs of ichthyomyines (Neusticomys and Rheomys, see Carleton 1973: fig. 6, the same specimens redrawn by Voss 1988: fig. 24), it differs by the unique configuration of the borderline fold and the posterior development of the glandular epithelium (Figure 5). In addition, the putative presence of a minute "orifice" in the borderline fold suggests that the glandular portion is mostly isolated (at least functionally?) from the main cavity. According to Voss (1988:313-314) "In Anotomys leander and in all species of Ichthyomys and Rheomys... for which material is available... the region between the esophagus and the pyloric sphincter is entirely lined with cornified squamous epithelium; glandular epithelium is restricted to a broad band that crosses the greater curvature on the right-hand side of the stomach". This is the condition shown by I. pinei and also supports the phylogenetic closeness among Anotomys, Ichthyomys and Rheomys (Voss 1988:446).

Ichthyomys pinei inhabits the Río León (Supplementary Figure S5) in an interandean valley, not far from where the 
first Chibchanomys orcesi Jenkins and Barnett (1997) were collected at the type locality on the Cajas Plateau, about 50 km NE Nabón (Jenkins and Barnett 1997). Although the two ichthyomyines occur at different elevations and in different environments, probably they are expressions of biological radiations associated with Andean geobiotic evolution. A Late Miocene age, ca. $9 \mathrm{MA}$, has been proposed for the origin of the interandean valleys in southern Ecuador (Hungerbühler et al. 1995, 2002). A rich mammal fauna has been described from their sedimentary deposits, indicating tropical environments associated with freshwater bodies (Anthony 1922, Hungerbühler et al. 1995, 2002, Carlini et al. 2014). Fossil Miocene rodents recorded from near Nabón are exclusively caviomorphs; ichthyomyines almost lack a paleontological record (see Voss 2015). The little evidence at hand consists of Holocene material referring to Anotomys and found in Carchi, northern Ecuador (Fejfar et al. 1993). Therefore, fossils do not help in reconstructing ichthyomyine historical biogeography. Molecular data point to an ancient origin for the tribe. The most recent inclusive analyses suggest that the split between Oryzomyalia and Sigmodontalia (i.e. Sigmodontini + Ichthyomyini) was around 10.8 MA (Steppan and Schenk 2017). Although this time estimation is based on weak fossil evidence, particularly for Sigmodontini (i.e. the fossil record used to calibrate the split of this tribe is provided by Prosigmodon, an extinct and poorly known genus that hardly can be assigned even to the Sigmodontinae), it provides a general framework for understanding ichthyomyine evolution. However, a seminal question posed by Voss (1988) is still unresolved, where this clade had its origin.

Ecuador is the country with the greatest diversity of ichthyomyine rodents, both measured in number of genera (four) and species (eight; Pardiñas et al. 2017, this paper). Except for Rheomys, all of the genera recognized in this tribe have been recorded from this country, although none is endemic (the recent detection of Anotomys in Colombia erased its Ecuadorean endemicity; see Marín-C and Sánchez-Giraldo 2017). With the description of Ichthyomys pinei, the number of species of Ecuadorean Ichthyomys increases to four. Several sigmodontine rodents new to Ecuador have been recorded in the last decade, including not only species previously known from elsewhere (e.g. Rhagomys longilingua, see Medina et al. 2017), but also new biological entities (e.g. Rhipidomys albujai, see Brito et al. 2017; Tanyuromys thomasleei, see Timm et al. 2018; Thomasomys salazari, see Brito et al. 2019). In addition, other taxa under study, representing new species, are soon to be published (R. Timm, pers. comm. to UFJP in 2018). Such flourishing richness surely will reorganize part of our understanding of Neotropical cricetids. In this context, results mandatory to establish rational and comprehensive programs of inventory and collection as well as to improve the access of students to these resources must be achieved. These programs should not be delayed, owing to the rapid rate of conversion of natural to human-modified environments.

Acknowledgments: We are indebted to Miguel Pinto and Juan P. Carrera (MEPN), Víctor Pacheco and Mercedes Veramendi (MSUM), and Robert Voss (AMNH), for providing access to the mammal collections under their care. We are also grateful to the Universidad del Azuay and its project funds UDA for financing the expedition to the type locality. Amanda Quezada (MZUA) and Germán Córdova kindly helped us with the field work in Azuay. Christophe Ronez and Diego Tirira shared with us photographs taken in the AMNH and NRM collections. Glenda Pozo (INABIO) collaborated with the artistic reconstruction of Ichthyomys pinei. Ronald H. Pine (University of Kansas) significantly improved the manuscript through a meticulous critical reading. Partial funding support for this research was provided by grant Agencia 2014-1039 (to UFJP). We are deeply grateful to all of the mentioned people and institutions.

\section{Appendix 1: List of specimens studied}

Specimens examined were in the following collections: AMNH, American Museum of Natural History (New York, NY, USA); MECN, Instituto Nacional de Biodiversidad (Quito, Ecuador); MEPN, Museo de la Escuela Politécnica Nacional (Quito, Ecuador); MUSM, Museo de Historia Natural, Universidad de San Marcos (Lima, Peru); MZUA, Museo Universidad del Azuay (Cuenca, Ecuador); QCAZ, Museo Pontificia Universidad Católica del Ecuador (Quito, Ecuador); and NRM, Natural Resource Management, University of Copenhagen (Copenhagen). These specimens were:

Anotomys leander $(\mathrm{n}=2)$ : Ecuador: Napo, Papallacta (QCAZ 6256), Cayambe, San Marcos (MECN 12580). Neusticomys monticolus ( $\mathrm{n}=8)$ : Ecuador: Carchi, Ârea de Amortiguamiento, Reserva Ecológica El Ángel (QCAZ1253032, MECN 5027); Cotopaxi, Bosque Integral La Otonga (QCAZ 13066); Pichincha, Tandayapa (QCAZ 6446, 6531), Puerto Quito (QCAZ 15898). Neusticomys peruviensis $(\mathrm{n}=1)$ : Peru: Madre de Dios, Río Manu, PN del Manu, Puesto de Vigilancia de Pakitza, 340 m (MUSM 9214). Neusticomys vossi $(n=9)$ : Ecuador: Morona Santiago, Parque Nacional Sangay, Tinguichaca (MECN 4332); Napo, Oyacachi (QCAZ 
927, 4145, 6257), Bermejo, Cabañas El Carrusel Mágico (QCAZ 7830), Las Caucheras, Cosanga (MEPN 5935), Volcán Sumaco (QCAZ 8956); Pastaza, Parque Nacional Llanganates (QCAZ 15249); Tungurahua, Reserva Natural Chamana Pamba (MECN 5029). Ichthyomys pinei, n. sp. $(\mathrm{n}=2)$ : Ecuador: Azuay, La Playa [MZUA 234 (holotype), MECN 5613 (paratype)]. Ichthyomys hydrobates $(\mathrm{n}=11)$ : Ecuador: Bolivar, Bosque Protector Cashca Tororas, (QCAZ 907), Chimborazo, Pallatanga, Los Santiagos (MECN 3960); Cotopaxi, San Francisco de las Pampas (QCAZ 818); Esmeraldas, Río Blanco (MEPN 5829-5831); Pichincha, Guápulo (NRM 586089-586093). Ichthyomys stolzmanni $(\mathrm{n}=4)$ : Ecuador: Morona Santiago, Río Jurumbuno (MECN 4914); Tungurahua, Río Zúñac (MEPN 12672), Zamora Chinchipe, Sabanilla (USNM 513625). Peru: Ayacucho, Huamanga, Piscigranja Arizona, cerca de Vinchos, 3397 m (MUSM 25808, 25809). Ichthyomys tweedii $(\mathrm{n}=6)$ : Ecuador: Azuay, Río Tenguel (MEPN 12229); El Oro, Río Santa Rosa (MECN 5772); Pichincha, Pachijal (MEPN 5832-5835). Ichthyomys sp. ( $\mathrm{n}=2)$ : Peru: Cajabamba, 3000 m (AMNH 11817/10109; examined through digital photographs).

\section{References}

Albuja, L., A. Almendáriz, R. Barriga, L.D. Montalvo, F. Cáceres and J.L. Román. 2012. Fauna de vertebrados del Ecuador. Escuela Politécnica Nacional, Quito.

Anthony, H.E. 1921. Preliminary report on Ecuadorean mammals. Am. Mus. Novit. 20: 1-6.

Anthony, H.E. 1922. A new fossil rodent from Ecuador. Am. Mus. Novit. 35: 1-4.

Anthony, H.E. 1923. Preliminary report on Ecuadorean mammals. Am. Mus. Novit. 55: 1-14.

ARCOM. 2015. Catastro minero del Ecuador. Available from http:// geo.controlminero.gob.ec:1026/geo_visor/ [2 March 2018].

Arellano, E. 2015. Genus Reithrodontomys Giglioli, 1874. In: (J.L. Patton, U.F.J. Pardiñas and G. D’Elía, eds.) Mammals of South America, Volume 2: Rodents. University of Chicago Press, Chicago, IL. pp. 61-63.

Braga, C. and R. Duda. 2017. New records and phylogenetic position of Neusticomys ferreirai (Rodentia: Cricetidae) Percequillo, Carmignoto and Silva, 2005 from the Amazon basin, northern Brazil. Mammalia 81: 635-639.

Brito, J. and U.F.J. Pardiñas. 2017. Stolzmann's crab-eating rat Ichthyomys stolzmanni. In: (D.E. Wilson, T.E. Lacher Jr., R.A. Mittermeier, eds.) Handbook of the mammals of the world. Volume 7: Rodents II. Lynx Edicions, Barcelona. pp. 406.

Brito, J., G. Tenecota and G. Pozo-Zamora. 2016. New record of Stolzmann's crab-eating rat Ichthyomys stolzmanni (Rodentia: Cricetidae) in Ecuador. Therya 7: 491-498.

Brito, J., N. Tinoco, D. Chávez, P. Moreno-Cárdenas, D. Batallas and R. Ojala-Barbour. 2017. New species of arboreal rat of the genus Rhipidomys (Cricetidae, Sigmodontinae) from Sangay National Park, Ecuador. Neotrop. Biodivers. 3: 65-79.
Brito, J., N. Tinoco, J. Curay, R. Vargas, C. Reyes-Puig, V. Romero and U.F.J. Pardiñas. 2019. Diversidad insospechada en los Andes de Ecuador: filogenia del grupo “cinereus" de Thomasomys y descripción de una nueva especie (Rodentia, Cricetidae). Mastozool. Neotrop. 26, in press.

Cabrera, A. 1961. Catálogo de los mamíferos sudamericanos. Rev. Mus. Argent. Cienc. Nat. 4: 309-732.

Carleton, M.D. 1973. A survey of gross stomach morphology in New World Cricetinae (Rodentia, Muroidea), with comments on functional interpretations. Misc. Publ., Zool. Univ. Michigan 146: 1-43.

Carleton, M.D. and G.G. Musser. 1989. Systematic studies of oryzomyine rodents (Muridae, Sigmodontinae): a synopsis of Microryzomys. Bull. Am. Mus. Nat. Hist. 191: 1-83.

Carlini, A.A., M.C. Castro, R.H. Madden and G.J. Scillato-Yané. 2014. A new species of Dasypodidae (Xenarthra: Cingulata) from the late Miocene of northwestern South America: implications in the Dasypodini phylogeny and diversity. Hist. Biol. 26: 728-736.

Catzeflis, F., B. de Thoisy, M.N. Ferreira da Silva and C.R. da Silva. 2017. Molar polymorphism and variation in tooth number in a semi-aquatic rodent, Neusticomys oyapocki (Sigmodontinae, Ichthyomyini). Mastozool. Neotrop. 24: 85-94.

Caviedes-Solís, I.W., I. Solano-Zavaleta, Y.A. Gómez-Jiménez and L. León-Panigua. 2017. Northernmost record and notes on the natural history of Rheomys mexicanus (Goodwin, 1959). Southw. Natur. 62: 92-94.

Elith, J., C.H. Graham, R.P. Anderson, M. Dudík, S. Ferrier, A. Guisan, R.J. Hijmans, F. Huettmann, J.R. Leathwick, A. Lehmann, J. Li, L.G. Lohmann, B.A. Loiselle, G. Manion, C. Moritz, M. Nakamura, Y. Nakazawa, J.M. Overton, A.T. Peterson, S.J. Phillips, K. Richardson, R. Scachetti-Pereira, R.E. Schapire, J. Soberón, S. Williams, M.S. Wisz and N.E. Zimmermann. 2006. Novel methods improve prediction of species' distributions from occurrence data. Ecography 29: 129-151.

Fejfar, O., G. Ficcarelli, C. Mezzabotta, M. Moreno-Espinosa, L. Rook and D. Torre. 1993. New finds of cricetids (Mammalia, Rodentia) from the late Pleistocene-Holocene of Northern Ecuador. Doc. Lab. Géol. Lyon 125: 151-167.

García, F.J., M. Machado, M.I. Delgado-Jaramillo, L. Aular and Y. Mújica. 2012. Nuevo registro de Ichthyomys pittieri (Rodentia: Cricetidae) para la Cordillera de la Costa Central de Venezuela, con notas sobre su historia natural y distribución. Mastozool. Neotrop. 19: 303-309.

Handley Jr., C.O. and E. Mondolfi. 1963. A new species of fish-eating rat Ichthyomys, from Venezuela (Rodentia: Cricetidae). Acta Biol. Venez. 3: 417-419.

Hanson, J.D., G. D’Elía, S.B. Ayers, S.B. Cox, S.F. Burneo and T.E. Lee. 2015. A new species of fish-eating rat, genus Neusticomys (Sigmodontinae), from Ecuador. Zool. Stud. 54: 49.

Hershkovitz, P. 1993. A new Central Brazilian genus and species of sigmodontine rodent (Sigmodontinae) transitional between akodonts and oryzomyines, with a discussion of muroid molar morphology and evolution. Fieldiana, Zool. n.s. 75: 1-18.

Hijmans, R.J., S.E. Cameron, J.L. Parra, P.G. Jones and A. Jarvis. 2005. Very high resolution interpolated climate surfaces for global land areas. Int. J. Climatol. 25: 1965-1978.

Hungerbühler, D., M. Steinmann, W. Winkler, D. Seward, A. Egüez, F. Heller and M. Ford. 1995. An integrated study of fill and deformation in the Andean intermontane basin of Nabón (Late Miocene), southern Ecuador. Sediment. Geol. 96: 257-279. 
Hungerbühler, D., M. Steinmann, W. Winkler, D. Seward, A. Egüez, D.E. Peterson and C. Hammer. 2002. Neogene stratigraphy and Andean geodynamics of southern Ecuador. Earth-Sci. Rev. 57: 75-124.

Jansa, S.A. and M. Weksler. 2004. Phylogeny of muroid rodents: relationships within and among major lineages as determined by IRBP gene sequences. Mol. Phylogenetics Evol. 31: 256-276.

Jenkins, P.D. and A. Barnett. 1997. A new species of water mouse, of the genus Chibchanomys (Rodentia, Muridae, Sigmodontinae) from Ecuador. Bull. Br. Mus. Nat. Hist. Zool. 63: 123-128.

Luna, L. and B.D. Patterson. 2003. A remarkable new mouse (Muridae: Sigmodontinae) from southeastern Peru: with comments on the affinities of Rhagomys rufescens (Thomas, 1886). Fieldiana Zool. ns 101: 1-24.

Marín-C, D. and C. Sánchez-Giraldo. 2017. Far away from the endemism area: first record of the Ecuador fish-eating rat Anotomys leander (Cricetidae: Sigmodontinae) in the Colombian Andes. Mammalia 81: 627-633.

Marín-C, D., J.D. Corrales-E and J.D. Valencia. 2018. Nuevos registros de la rata cangrejera Ichthyomys hydrobates (Winge, 1891) (Rodentia: Cricetidae) en Colombia. Mastozool. Neotrop. 25: 235-243.

Medina, C.E., E. López, K. Pino, A. Pari and H. Zeballos. 2015. Biodiversidad de la zona reservada Sierra del Divisor (Perú): una visión desde los mamíferos pequeños. Rev. Peru. Biol. 22: 199-212.

Medina, C.E., D.R. Díaz, K. Pino, A. Pari and H. Zeballos. 2017. New locality records of Rhagomys longilingua Luna \& Patterson, 2003 (Rodentia: Cricetidae) in Peru. Check List 13: 2136.

Ministerio del Ambiente. 2013. Sistema de Clasificación de los Ecosistemas del Ecuador Continental. Subsecretaría de Patrimonio Natural, Quito.

Musser, G.G. and A.L. Gardner. 1974. A new species of the ichthyomyine Daptomys from Perú. Am. Mus. Novit. 2537: 1-23.

Narváez-Romero, C., C. Reyes-Puig, D. Valle and J. Brito. 2018. New records and estimation of the potential distribution of the stump-tailed porcupine Coendou rufescens. Therya 9: 137-146.

Pacheco, V. and J. Ugarte-Núñez. 2011. New records of Stolzmann's fish-eating rat Ichthyomys stolzmanni (Cricetidae, Sigmodontinae) in Peru: a rare species becoming a nuisance. Mamm. Biol. 76: 657-661.

Pardiñas, U.F.J., P. Teta and G. D’Elía. 2009. Taxonomy and distribution of Abrawayaomys (Rodentia: Cricetidae), an Atlantic Forest endemic with the description of a new species. Zootaxa 2128: 39-60.

Pardiñas, U.F.J., D. Ruelas, J. Brito, L.C. Bradley, R.D. Bradley, N.O. Garza, B. Krystufek, J.A. Cook, E.C. Soto, J. Salazar-Bravo, G.I. Shenbrot, E.A. Chiquito, A.R. Percequillo, J.R. Prado, R. Haslauer, J.L. Patton and L. León-Panigua. 2017. Family Cricetidae (true hamsters, voles, lemmings and New World rats and mice)-Species accounts of Cricetidae. In: (D.E. Wilson, T.E. Lacher Jr. and R.A. Mittermeier, eds.) Handbook of the mammals of the world. Volume 7: Rodents II. Lynx Edicions, Barcelona. pp. 280-535.
Patton, J.L., U.F.J. Pardiñas and G. D’Elía. (Eds.) 2015. Mammals of South America, Volume 2: Rodents. University of Chicago Press, Chicago, IL.

Pearson, R.G., C.J. Raxworthy, M. Nakamura and A.T. Peterson. 2007. Predicting species distributions from small numbers of occurrence records: a test case using cryptic geckos in Madagascar. J. Biogeogr. 34: 102-117.

Phillips, S.J., R.P. Anderson, and R.E. Schapire. 2006. Maximum entropy modeling of species geographic distributions. Ecol. Model. 190: 231-259.

Reig, O.A. 1977. A proposed unified nomenclature for the enameled components of the molar teeth of the Cricetidae (Rodentia). J. Zool. (London) 181: 227-241.

Rodríguez-Posada, M.E. 2014. Primer registro del ratón de agua del Táchira, Neusticomys mussoi (Rodentia, Cricetidae) en Colombia. Mastozool. Neotrop. 21: 367-372.

Salazar-Bravo, J., U.F.J. Pardiñas, H. Zeballos and P. Teta. 2016. Description of a new tribe of sigmodontine rodents (Cricetidae: Sigmodontinae) with an updated summary of valid tribes and their generic contents. Occas. Pap. Mus. Tex. Tech Univ. 338: 1-13.

Santillán V. and E. Segovia. 2013. Primer registro de la rata cangrejera de Tweedy Ichthyomys tweedii (Sigmodontinae: Ichthyomyini) en la provincia del Azuay, Ecuador. Mastozool. Neotrop. 20: 421-424.

Schenk, J.J., K.C. Rowe and S.J. Steppan. 2013. Ecological opportunity and incumbency in the diversification of repeated continental colonizations by muroid rodents. Syst. Biol. 62: 837-864.

Steppan, S.J., and O. Ramirez. 2015. Genus Phyllotis Waterhouse, 1837. In: (J.L. Patton, U.F.J. Pardiñas and G. D’Elía, eds.) Mammals of South America, Volume 2: Rodents. University of Chicago Press, Chicago, IL. pp. 535-555.

Steppan, S.J. and J.J. Schenk. 2017. Muroid rodent phylogenetics: 900-species tree reveals increasing diversification rates. PLoS One 12: e0183070.

Thomas, 0. 1893. On some mammals from central Peru. J. Zool. 23: 333-341.

Timm, R.M., R.H. Pine and J.D. Hanson. 2018. A new species of Tanyuromys Pine, Timm, and Weksler, 2012 (Cricetidae: Oryzomyini), with comments on relationships within the Oryzomyini. J. Mammal. 99: 608-623.

Vorontsov, N.N. 1967. Evolution of the alimentary system in myomorph rodents (in Russian). Nauka, Siberian Branch, Novosibirsk.

Voss, R.S. 1988. Systematics and ecology of ichthyomyine rodents (Muroidea): patterns of morphological evolution in a small adaptive radiation. Bull. Am. Mus. Nat. Hist. 188: 262-493.

Voss, R.S. 2015. Tribe Ichthyomyini Vorontsov, 1959. In: (J.L. Patton, U.F.J. Pardiñas and G. D’Elía, eds.) Mammals of South America, Volume 2: Rodents. University of Chicago Press, Chicago, IL. pp. 279-291.

Supplementary Material: The online version of this article offers supplementary material (https://doi.org/10.1515/mammalia-20190022). 